\title{
SO FAR AND YET SO CLOSE: \\ DIFFERENCES AND SIMILARITIES \\ RELATED TO THE SITUATION \\ OF THE PEASANTRY WITHIN \\ THE SEIGNEURIAL FRAMEWORK \\ IN MANORIAL ENGLAND \\ AND GALICIA $\left(12^{\mathrm{TH}}-14^{\mathrm{TH}}\right.$ CENTURIES)
}

\section{TAN LEJOS Y AUN ASÍ TAN CERCA: DIFERENCIAS Y SIMILITUDES EN RELACIÓN CON LA SITUACIÓN DEL CAMPESINADO DENTRO DE LA ESTRUCTURA FEUDAL EN LA INGLATERRA «MANORIAL» Y EN GALICIA (SIGLOS XII-XIV)}

José Antonio López Sabatel ${ }^{1}$

Recepción: 2014/12/2 . Comunicación de observaciones de evaluadores: 2015/2/13 .

Aceptación: 2015/2/25

DOI: http://dx.doi.org/10.5944/etfiii.28.2015.14875

\section{Abstract}

This article addresses the legal and social status of both Galician and English landholders between the twelfth and the fourteenth centuries. In addition, it sheds some light on the different mechanisms used by the lordship in both territories to control the space and subdue the peasantry. Peasants and their relationship with the seigneurial system are the main components of this work and, consequently, it has been necessary to underline their ties and obligations as a diversified social class within the feudal framework. Also of significance is the different means employed for them to put up a varied resistance against that form of subjugation. In order to carry out this comparative study, it has been essential to perform a deep analysis of published primary sources as well as a specialised 
bibliography. The findings from this analysis yield the following conclusion: in spite of their legal status, Galician peasants shared many features in common with unfree English tenants.

\section{Keywords}

Peasantry; England; Galicia; Lordship; Manor; Foro

\section{Resumen}

Este artículo pretende abordar el estatus tanto de los tenentes gallegos como ingleses entre los siglos doce y catorce, además de arrojar cierta luz sobre los diferentes mecanismos utilizados por el señorío en ambos territorios para controlar el espacio y someter al campesinado. Los campesinos y su relación con el sistema señorial son los principales protagonistas de este trabajo y, en consecuencia, ha sido necesario subrayar sus obligaciones y ataduras como la clase social diversificada que eran en el seno de la estructura feudal. De importancia, también fueron los diferentes medios utilizados por estos con el fin de erigir una resistencia de diversa índole contra tal subyugación. Con el propósito de llevar a término este estudio comparativo, ha sido fundamental un profundo análisis de fuentes primarias ya publicadas, así como de una especializada bibliografía. Los resultados derivados de tal análisis han expuesto la siguiente conclusión: a pesar de su estatus legal, los campesinos gallegos compartieron muchos rasgos característicos en común con los tenentes no libres ingleses.

\section{Palabras clave}

campesinado; Inglaterra; Galicia; señorío; manor; foro 
THE AIM OF THIS STUDY is to identify common features and different ways of shedding light on the status of both English and Galician peasants within the feudal framework. Based on the analysis of the similarities, it will be possible to extend our knowledge of medieval peasant society as a universal entity beyond 'national' and 'cultural' restrictions. On the other hand, the examination of the differences will show the importance of internal factors that are specific to each area as a result of redefining the general trends that are characteristic of the period studied. The choice of the Midlands and South-Central England is mainly based on the great deal of information available for these areas. It would not be unfair to say that historians are slaves to their sources and these sources are available in the form of the records of the manor court. The profusion of such documentation has been the reason that explains the importance given to this territory by the English medieval historiography in order to explore the peasant society. In the case of Galicia, it was the foro which gained prominence as a historical resource, and as happened to the manorial records, everything related to the peasant's lives that failed to appear in such texts, was meant, somehow, to be side-lined and lost to oblivion. Thus, medievalists tend to know much more about villein tenants and foreros, which, although only just a part of the medieval peasantry, have been considered as its whole. The interest in addressing the peasant state in such distant territories lies in comparing the lives of those who lived under the custom of the manor to those who had to obey the rules of the foro. That is to say, if there is any possibility of considering the feudal bonds that tied the day-to-day peasant's existence as a homogeneous object of study beyond geographical limitations and substantial differences between such disparate seigneurial regimes: the English one, which was customary and clung to the direct management of the state, and the Galician one, which was legalistic and focused on the indirect exploitation of the land. In addition, it would be interesting to draw a whole picture of how the hierarchy is articulated inside both peasants' societies and in which way the varied types of resistance were carried out in both territories.

In order to conduct such a comparative study, it will be necessary to address the following key points: the different ways in which feudalism was articulated and consolidated, both in Galicia and England. Strictly speaking, this means performing an analysis of the social and legal mechanisms which enabled the lordship to be structured. It is useful to examine the role of the manor and the coto, both as scenes of feudalization, in developing the framework of dependence in which the peasantry existed, as well as to examine their dominant power over the nature of medieval rural life. The contrasting arrangements of land tenure and social stratification in connection with the area of the land cultivated and the specific status of the landholders is also a useful avenue for research. In addition, one might look at the differences between English and Galician tenant types according to the various degrees of freedom within the feudal relationship; the divergent means by which peasants would access the overlord's land as vassals; 
the relationship between peasants and overlords based on the context of feudal income, burdens, and requirements, and to seigneurial jurisdiction as the possible genesis of class conflict and social antagonism in the form of several ways of resistance. Finally, the contrasting means of extracting income can highlight the differences and similarities between the two countries concerning both land ownership and jurisdictional burdens claimed by the overlords.

\section{FREE AND UNFREE TENANTS}

The first remarkable point to address is the one concerning the law and the personal situation of the peasantry. In this aspect, both Galicia and England share the same starting point; that is to say, a clear division of the peasant society between free and unfree individuals, but in England, unlike what happened in the north-west of Spain, this differentiation, at least referred to its legal character, practically lingered throughout the entire Middle Ages. It is important to mention at this point that despite legal considerations, both free Galician and unfree English peasantry were submitted to similar burdens and bonds common to their dependent status within the feudal framework. In this way, the diverse categories of the Galician peasantry, according to their varying degrees of legal freedom, faded during a process which ended by the early $\mathrm{I}^{\text {th }}$ century. In I2I9, any mention concerning the term 'serf' had entirely disappeared from the records of the monastery of Sobrado $^{2}$. Thus, with the triumph of indirect farming, the Galician countrymen shared an equal legal status within the ties of dependence toward the overlord 3 . These bonds were articulated by a typical agrarian contract called the foro, thereby lordship could extend beyond the original territorial boundaries of seigneurial jurisdiction ${ }^{4}$ and, over time, any reference concerning the term servus tended to disappear by turning land into tenure in return of feudal income ${ }^{5}$. This process was also common in England for over the $\mathrm{II}^{\text {th }}$ and $13^{\text {th }}$ centuries, particularly through the distinctive lines between villeins and servi. A distinction that even though was remarkably significant during the Anglo-Saxon and early Normand periods, eventually faded into a same overwhelmed class ${ }^{6}$. Over the twelfth century, the whole process was marked by stressing the unfree status of the majority of the peasantry. In such a way, the word rusticus meant that a peasant was

2. Pallares Méndez, María del Carmen \& Portela Silva, Ermelindo: 'El lugar de los campesinos. De repobladores a repoblados' in Rodríguez, Ana (ed.): El lugar del campesino en torno a la obra de Reyna Pastor, Valencia, cSIC, 2007, p. 66.

3. MARIÑo VeIRAS, Dolores: Señorío de Santa María de Meira (de 1150 a 1525). Espacio rural, régimen de propiedad y régimen de explotación en la Galicia medieval, La Coruña, Ediciones Nos, 1983, p. 176.

4. Pallares Méndez, María del Carmen: 'Los cotos como marco de los derechos feudales en Galicia durante la Edad Media (1100-1500)', Liceo franciscano, 31 (1978), pp. 201-225.

5. Pallares Méndez, María del Carmen \& Portela Silva, Ermelindo: 'El lugar de los..., p. 66.

6. Schofield, Philipp R.: Peasant and Community in Medieval England. 1200-1500, Basingstoke, Palgrave Macmillan, 2003, p. 13 . 
unfree ${ }^{7}$. By II90, the monks of Worcester were making a conceptual distinction between liberi homines (free men) and rustici. The same happened with the term villanus, or villager, which was applied to 40 per cent of the rural population of Domesday Book. This term would take on the newly concrete meaning of villein accompanied by the abstract noun villeinage. A charter of the iIgos refers to 'the whole lordship that I and my predecessors had in that land, in demesne and in the free tenements and in the villeinages.

The differentiating features referring to English unfree and free tenants are widely known and firmly established at the end of the $12^{\text {th }}$ century. After legal reforms undertaken by Henry II, which aimed to determine which sections of the population were under the jurisdiction of the royal courts (or those who were free), it was concluded that about the 40 percent of the peasantry were unfree villeins subjugated to the authority of their lords ${ }^{9}$. This part of the peasantry was committed to bearing a greater weight of seigneurial obligations, and thus shared certain similarities to the burdens felt by the Galician peasants. Among them, labour services were the most common. The unfree peasants were obliged to work the lord's land, called 'demesne', for a period settled by the custom of the manor, and this is the reason why they were known as customary tenants. There were at least four categories of labour services to be completed by the villeins: weekly work, seasonal work, boon work, and carrying services. The first ones were the most necessary and onerous, for the peasant would have to work two or three days in the lord's demesne carrying out a wide range of tasks, from dung-spreading, digging ditches, or erecting fencing to ploughing, reaping, or threshing, always at the discretion of the lord's officers ${ }^{\mathrm{IO}}$. Moreover, during the busiest seasons of the agricultural year, villeins were required to perform additional work activity as well as to submit extra days of their own time to satisfy concrete demands called 'boon work' on the ground that this service would be done by the kindness and goodwill of the tenant rather than at the lord's willir. Finally, on some occasions, the unfree tenants were subject to carrying agricultural products, whether to the nearest market or to the manor house or to the lord's premises, using their own means of transport ${ }^{12}$. By contrast, free tenants enjoyed a more privileged situation

7. Darlington, Reginald Ralph: The Cartulary of Worcester Cathedral Priory, Oxford, The Pipe Roll Society, 1968, pp. 178-179.

8. MADOX, Thomas: Formulare Anglicanum, or, A Collection of Ancient Charters and Instruments of Divers Kinds Taken From the Originals, Placed Under Several Heads, and Deduced (in a Series According to the Order of Time) From the Norman Conquest to the End of the Reign of King Henry the VIII, London, Jacob Tonson and R. Knaplock, 1702, p. 274.

9. DYER, Christopher: 'The Economy and Society', in SAUL, Nigel (ed.): The Oxford illustrated history of medieval England, Oxford, Oxford University Press, 1997, p. 150.

10. BAILey, Mark: Medieval Suffolk: An Economic and Social History, 1200-1500, Woodbridge, The Boydell Press, 2007 , p. 52.

11. Salzmant, Louis Francis: English Life in the Middle Ages, London, Oxford University Press, 1926, p. 46.

12. BeNNET, Henry Stanley: Life on the English Manor: A Study of Peasant Conditions, 1150-1400, London, Cambridge University Press, 1938, p. 109. 
as they satisfied fixed rents in cash or kind ${ }^{13}$ and, still more importantly, in pre-set few labour services attached to the tenure and therefore oblivious to the lord's changing whims ${ }^{\mathrm{I}}$. However, in Galicia, all the labour services were included in the foro so, initially, all the tenants were aware of these burdens from the very first moment in which they agreed to honour this agrarian contract. Thus unlike the English peasants, labour services never drew a clear difference between free and unfree obligations, because the weight of these commitments lay in proportional rents (mainly a share of the crop) devised to be satisfied by the vassals and with the aim of both providing supplies for the lords and protecting the seigneurial income from inflationary periods $s^{15}$. This is the reason why labour services were less common and softer in Galicia than in England; in fact, these ties were meant to be an additional duty assigned in order to guarantee the peasants' acknowledgement of lords' feudal rights over the land in lieu their personal properties ${ }^{16}$. In this respect, it would not be a mistake to deem Galician tenants with a similar legal and social status as similar to free English peasants, since both were bound to fulfil fixed rents and pre-set labour tasks. Such tasks were varied and focused on completing a little sporadic farming work in the lord's demesne, in addition to building and repairing services at the seigniorial premises, as well as (though only on rare occasions) transporting the required rent to the lord's facilities. Over time, in the early fourteenth century, this feudal imposition was on the wane due to its commutation into cash $^{17}$. In many cases, it would be much more profitable for the lords to hire a workforce rather than compel unwilling villeins to perform labour services. For instance, at Battle Abbey the value of the meals provided to the tenants considerably exceeded the cost of hired workers ${ }^{18}$. It was also the case that hired labourers worked more efficiently than did villeins doing compelling customary services ${ }^{19}$. In England, these changes likely affected the main source of feudal income ${ }^{20}$, in Galicia, only a minor part of that was modified. Lords were far more interested, throughout the entire Middle Ages, in acquiring rent in kind or cash rather than in the form of work.

\footnotetext{
13. Forgeng, Jeffrey L.: Daily Life in Medieval Europe, Westport, Greenwood Press, 1999, p. 75.

14. VoLoKH, Alexander: 'Contract Choice and Legal Change in Medieval England' [on line], available on http:// www.volokh.com/sasha/medo518.pdf.

15. Ríos Rodríguez, María Luz: As orixes do foro na Galicia medieval, Santiago, Universidad de Santiago, 1993, pp. $87-88$.

16. Álvarez Álvarez, Eleutino: 'Las exigencias señoriales en la Galicia meridional a través de la duración y la renta de los contratos de foro (1340-1450)', Cuadernos de estudios gallegos, 34 (1983), pp. 117-152.

17. Clemente Ramos, Julián: 'Las sernas en el Becerro de las Behetrías', Homenaje al profesor Juan Torres Fontes, 1 (1987), pp. 299-318.

18. SeARLE, Eleanor: Lordship and community: Battle Abbey and its banlieu, 1066-1538, Toronto, Pontifical Institute of Mediaeval Studies, 1974, pp. 176-179.

19. Stone, David: 'The Productivity of Hired and Customary Labour: Evidence from Wisbech Barton in the Fourteenth Century', The Economic History Review, 50 (1997), pp. 640-655.

20. Postan, Michael Moïssey: Essays on medieval agriculture and general problems of the medieval economy, Cambridge, Cambridge University Press, 2008, p. 89.
} 


\section{LORDSHIP AND PROPERTY RIGHTS}

It is well-known that in England, and above all, in the Midlands, the main feature linked to the extension of the feudal system is the manorialisation process by which there was no lord without land and no land without a lord. The origins of the manor seem to date back to the ninth century, the monarchy granted some territories and remarkable jurisdictional rights to the church and nobles for the purpose of forging alliances and winning loyalties ${ }^{21}$. After the Norman Conquest, the process intensified and the peasants, who during the Anglo-Saxon period were loosely linked to the development of the seigneurial economy, were aware of their loss of autonomy within the Normand feudal framework. They fell into deep bonds of dependency and were subjected to more burdens and restrictions ${ }^{22}$. As a matter of fact, by the II $^{\text {th }}$ century, all of England had been divided into manors, which were leading economic and administrative centres from which the lords exercised their power over the rest of the inhabitants ${ }^{23}$. In this way, it was likely to find manors in different places held by the same lord and, conversely, manors established in the same locality which belonged to diverse lords, but be that as it may, there was land that was not under the rule of a $\operatorname{lord}^{24}$. So, if a tenant held land outside a determined manor, it would be presumable that his tenure was confined to another manor ${ }^{25}$. This explains the non-existence of property rights as are currently known, because, during the English Middle Ages, the territorial and jurisdictional expansion of the lordship made this legal term entirely unnecessary. The fact was that everyone with land, except the king, was someone's tenant and held land of their lord ${ }^{26}$. Thus, the lords were more than mere owners, they were rulers and legislators.

However, property emphasized a substantial difference between lordships both in England and Galicia, as well as the means used to manage the exploitation of the land. In Galicia, it is well-known the importance given to feudal agrarian contracts so that the monasteries were able to expand feudal power further away from the boundaries of the original coto. At that point, property rights become more important in the sense that they laid the foundations on which the dependency relationships were grounded by transferring land in return for vassalage

\footnotetext{
21. Harvey, Barbara: 'The life of the manor' in Williams, Ann \& Erskine, R.W.H. (eds.): The Oxfordshire Domesday Book: studies, Oxford, Alecto, 1987, pp. 39-42.

22. FAITH, Rosamond: The English peasantry and the growth of lordship, London, Leicester University Press, 1997, pp. $178-265$.

23. AsHLEY, William James: An introduction to English economic history and theory (The Middle Ages), London, Rivingtons, 1888, p. 6.

24. WhitTLE Jane \& YATES, Margaret: 'Pays réel or pays légal? Contrasting patterns of land tenure and social structure in eastern Norfolk and western Berkshire, 1450-1600', The Agricultural History Review, 48.1 (2000), pp. 1-26.

25. Tomkins, Mathew: Peasant Society in a Midlands Manor, Great Horwood 1400-1600, Doctoral Thesis, Leicester, University of Leicester, 2006, p. 92.

26. BAKER, John Hamilton: An Introduction to English Legal History, London, Butterworths, 1990, pp. 255-256.
} 
and income. Here, is important to highlight two different trends related to the exploitation of the land when it comes to both English and Galician lands. In England, from the early $\mathrm{I}^{\text {th }}$ century onward, the direct management of the manors became more and more popular ${ }^{27}$. By contrast, in north-west Spain and for the same period of time, indirect management mostly succeeded. This is the reason that explains the relevance of labour services in most of England and their poor presence in the case of Galicia. Moreover, given the increasing level of manorialisation in England, the strength of the territorial and jurisdictional lordship over the peasantry, and the significance of direct management of the land, there was no need for the lords to produce farm lease agreements to guarantee the obedience and loyalty of the tenants. Nevertheless, in Galicia, these legal deeds constituted the cornerstone on which all the feudal relationships were built. In fact, it was common to see the lands belonging to one lord and granted through foral arrangements in places under another lord's jurisdiction ${ }^{28}$. The acquisition of the property and its subsequent leasing to prospective tenants not only implemented personal ties within the feudal framework, but also established a subjugating and a captivating method by which the peasant was able to have access to the land. Hence, the main characteristic feature of Galician lordship was the gathering as an indivisible whole of both jurisdictional and property rights ${ }^{29}$.

\section{UNFREE AND FREE TENURES}

The legal condition and social consideration of the English tenants had nothing to do with the status of the land that was held, but with their hereditary obligation to undertake labour services ${ }^{30}$. These burdens were deeply linked to the legal character of the tenure. Nevertheless, free and unfree tenures did not necessarily correspond to free and unfree men, inasmuch as free men in dire straits might be forced to hold an unfree tenure and meet mandatory duties at the lord's whim. On the other hand, the authors of surveys identified these tenurial allegiances as proof of personal legal status because an unfree tenant was not allowed to hold free land ${ }^{3}$.

As in the case of Galicia, in England, the lords became landowners through a process which started with the assignment by the monarch of exclusive jurisdictional

27. STACY, Norman: 'The state of the demesne manors of Glastonbury Abbey in the twelfth century', in Evans, R. (ed.): Lordship and learning: studies in memory of Trevor Aston, Woodbridge, Boydell Press, 2004, p. 109.

28. López SABATEL, José Antonio: 'Rentas y exigencias feudales en la tierra de Lemos durante la Baja Edad Media (siglos XIV y XV)', Anuario de Estudios Medievales, 41.1 (2011), pp. 211-234.

29. VILLA-AMIL Y CASTRO, José: Los foros de Galicia en la Edad Media: estudio de las transformaciones que ha sufrido en Galicia la contratación para el aprovechamiento de las tierras, Madrid, Establecimiento tipográfico de los sucesores de Rivadeneyra, 1884, pp. 61-117.

30. HILTON, Rodney: The decline of serfdom in Medieval England, London, Palgrave Macmillan, 1982, p. 12.

31. Hudson, John: The Oxford history of the laws of England 871-1216, v. 2, Oxford, Oxford University Press, 2012, p. 663. 
power over an inhabited territory. In order to subdue the peasants and create dependency bonds, the lords granted pieces of land, together with livestock and equipment, in exchange for onerous work services ${ }^{32}$. As for the expansion of the ecclesiastical lordship, the similarities with the Galician feudalisation process are considerable. Small freeholders fell into the commendation of great abbeys and monasteries and became vassals, either by giving their lands away in return for more suitable tenures to guarantee their survival, or receiving plots in precaria as a loan ${ }^{33}$. In the matter of the composition of the tenures, there were few differences between manorial England and Galicia. It is usual to find, in extents and surveys, the holdings described as a messuage with croft adjacent ${ }^{34}$; that is to say, a whole homestead with its main house, outbuildings, along with orchards and gardens ${ }^{35}$ and such a description fits what is known in Galicia as a casa $3^{6}$. The casal used to be the undisputed star in the Galician foros, given the overlords' interest in controlling the territory by framing their vassals in those farming and dwelling units ${ }^{37}$.

It is known that the presence of villeins was predominant in manorial England, which explains the importance given by the surveys when it comes to unfree tenure; however, this does not mean the complete absence of references concerning the free tenures. In Leicester, free land could be inherited, purchased by agreement, or granted by the holder without seigneurial permission as long as the recipient was another freeman. In order to hold the land, the tenant had to pay an entry fine and rent in cash was the main render on free holdings, although the amount annually payable was relatively fixed and immutable. Furthermore, the tenant was required to attend the lord's court, as well as, perform light carrying services ${ }^{38}$.

Nonetheless, manorial records were focused on unfree tenures, which were the main source of rent, workforce, customs, services, and obligations owed to the lord. These holdings were called customary since they were ruled by the custom of the manor ${ }^{39}$ and this pattern sets up another similarity with Galician peasants' daily life, for the foro, in its dual condition of both lease and seigneurial agreement, was used to establish several obligations to be fulfilled by the tenant according the

32. DYER, Christopher: Making a living in the Middle Ages. The people of Britain 850-1520, London, Penguin Books, 2003 , P. 37.

33. BARLOW, Frank: The feudal kingdom of England 1042-1216, London, Longmans, 1966, p. 10. See for the same situation in Galicia Ríos Rodríguez, María Luz: 'Propiedad de la tierra y relaciones señoriales: el Praestimonium, en Galicia (1150-1350)', in Serrano Martín, Eliseo \& SARASA SÁncheZ, Esteban (coords.): Señorío y feudalismo en la Península Ibérica (ss. XII-XIX), vol. 3, Zaragoza, Institución 'Fernando el Católico', 1993, pp. 197-207.

34. Dyer, Christopher: Everyday life in Medieval England, London, Hambledon and London, 2000, p. 69.

35. RAfTIS, James: Peasant Economic Development within the English Manorial System, Montreal, McGill-Queen's University Press, 1996, p. 12.

36. BOU HIER, Abel: Ensaio xeográfico de análise e interpretación dun vello complexo agrario, vol. 2, s.l., Xunta de Galicia, 2001, p. 1212.

37. Portela Silva, Ermelindo: La Región del obispado de Tuy en los siglos XII a xv. Una sociedad en la expansión y en la crisis, Santiago de Compostela, El Eco Franciscano, 1976, pp. 85-86.

38. McLoughuin, Vanessa: Medieval Rothley, Leicestershire: manor, soke and parish, Doctoral Thesis, Leicester, University of Leicester, 2006, p. 83-84.

39. SChofield, Philipp. R.: Peasant and community in..., p. 41 
custom of either the coto or the land $4^{40}$. This feudal and agrarian contract reveals one of the most significant differences between English and Galician peasants with regard to their capacity for accessing the lord's land and becoming tenants. Throughout manorialised England, tenure holdings entirely depended on the lord's will and the villein was bound to swear an oath of fealty and pay an entry fine as a token of the lord's whim to bequeath land ${ }^{41}$. In principle, the lord was free to turn the tenant out whenever he wished, although, over time it became a customary use for the vassal to inherit the land by paying the entry fine $e^{42}$. All the same, the Galician lord's will is reflected in the conditions to be fulfilled by the tenant at the time that the land was bestowed through the farming contract and, as a consequence, the will would remain immutable throughout the length of such a two-sided agreement. Both English and Galician lords were concerned about keeping the land inhabited by vassals sharing the same social condition in order to ensure that the onerous services of individual holdings would prevail and that they would never be forgotten. In this sense, English tenancies were, according to a restrictive clause, "held until a tenant shall be found who will perform the due and accustomed services'43, whereas in Galicia it is usual to find similar clauses designed to prevent the tenant from giving away land to those who did not share their vassal status ${ }^{44}$. Likewise, the Statute of Quia Emptores of 1290 enacted by Edward I would forbid subinfeudation, so the new holder of the land would take place of the seller and hold the land directly from the overlord ${ }^{45}$. Apart from services and rent, English peasants were bound to satisfy special requirements to preserve the granted plot. These demands were intended to maintain the tenure as when received with regard to buildings, equipment, and productivity ${ }^{46}$. An identical situation was recorded by Galician surveys, in which it can be seen how peasants were compelled to undertake specific tasks in order to increase their production, in addition to repair and even build houses and outbuildings ${ }^{47}$.

\section{FEUDAL LEVIES AND BURDENS}

It has been said above that when it comes to legal obligations as a holder of the tenure, which the Galician peasant was compelled to fulfil (namely, fixed rents and pre-set labour tasks), his state might certainly be equated to an English free

\footnotetext{
40. López Sabatel, José Antonio: 'Rentas y exigencias...', pp. 211-234.

41. Новвs, Daphne Angela: Manor Village and Individual in Medieval England, Doctoral Thesis, Victoria, University of Victoria, 1998, pp. 91-92.

42. FORGENG, Jeffrey L.: Daily life in..., p. 73.

43. Harvey, Philip D.A.: The Peasant Land Market in Medieval England, Oxford, Clarendon Press, 1984, p. 124.

44. Ríos Rodríguez, María Luz: As orixes do..., p. 230.

45. Plucknett, Theodore Frank Thomas: Legislation of Edward I, Oxford, Clarendon Press, 1949, pp. 102-108.

46. Raftis, James Ambrose: Peasant Economic..., p. 13.

47. López Sabatel, José Antonio: 'Rentas y exigencias...', pp. 228-229.
} 
man's. Nonetheless, apart from the ties attached to the mere usufruct of the land, the Galician peasantry would be bound to satisfy other requirements like those connected to the lordship derived from the use and custom of the land and remarkably contained in the clauses of the farming contracts ${ }^{4}$. In this aspect, similarities between Galician tenants and unfree English landholders become far more evident. The aim of this section is to draw attention towards those comparable seigneurial levies and burdens which had to be complied with, both in the north-west of Spain and the English manor.

One of the most common burdens to be borne by the peasantry in the Galician countryside was called derechura, meaning the obligation for the tenant to render a fixed amount of cash or kind as an acknowledgement of seigneurial rights. This tax was used to levy the output of those minor crops excluded from the main agrarian income, such as orchards, fruit trees, as well as linen and flax gardens ${ }^{49}$. In England, this onerous servile incident was known as 'tallage' and in Galicia it seems to have been first imposed by the thirteenth century ${ }^{50}$. Another strong likeness is that the size and regularity of both derechura and tallage were regulated by custom and their last aim, as a land tax, was to secure the total subjection of the tenant to the lord's domain ${ }^{51}$.

I have previously stressed that in Galicia, the proportional rent meant that in order to till the soil the tenant had to give away a share of the crop. This system was popular in the thirteenth and fourteenth centuries and was used by the lords, because it allowed them to exercise far more effective and closer control over the indirect management of the land ${ }^{52}$. By contrast, in England, the sharecropping or champart rent had little relevance. This difference to north-west Spain can be explained by various reasons. In the first place, it can be argued that sharecropping had no precedent in the customs of the manor and it would have been a challenge to successfully introduce this model ${ }^{53}$. Secondly, and according to Hilton, lords preferred to collect their revenue in cash due to the stability of the sterling currency. Besides, this way of raising income used to be the best means to prevent direct producers from cheating the landlords of their proper share of the whole output ${ }^{54}$.

48. Álvarez, Eleutino: 'Las exigencias señoriales...', p. 117.

49. López Sabatel, José Antonio: 'Cultivos agrícolas en la Ribeira Sacra durante los siglos xıv y xv', Espacio, Tiempo y Forma. Serie III, 20 (2007), pp. 183-198.

50. DYER, Christopher: Lords and Peasants in a Changing Society. The Estates of the Bishopric of Worcester, 680-1540, Cambridge, Cambridge University Press, 1980, p. 103. Ríos Rodríguez, María Luz, As orixes do foro..., pp. 142-145.

51. Fernández Fernández, Adolfo: O Mosteiro femenino de San Miguel de Bóveda na Idade Media. Estudo histórico e colección documental (séculos XII-XV), A Coruña, Toxosoutos, 2005, p. 45. SCHOFIELD, Philipp. R.: Peasant and community in..., p. 27.

52. Sánchez Carrera, María del Carmen: El Bajo Miño en el siglo xv. El espacio y los hombres, A Coruña, Instituto de Estudios Gallegos Padre Sarmiento, 1997, p. 142.

53. ReEd, Clyde \& ANderson, Terry: 'An Economic Explanation of English Agricultural Organization in the Twelfth and Thirteenth Centuries', Economic History Review, 25.I (1973), pp. 134-137.

54. HILTON, Rodney: 'Why was there so little champart rent in medieval England?', The Journal of Peasant Studies, 17.4 (1990), pp. 509-519. 
Another burden which deserves to be highlighted, given its strong presence in the documentation of the period and shared by both English and Galician tenants, concerns the obligation to provide itinerant lords with food and lodge. Initially known as yantar and posada in Spain, they were royal rights that from the eleventh century on were gradually acquired by the nobility as it would be with the judicial prerogatives. Not only were the lords entitled to demand this feudal right, but they also sent their agents to measure and collect the seigniorial proportional share of the crops. Over time and especially in the southern areas of Galicia, it was common to find this imposition commuted into money55. Nonetheless, its final purpose would remain the same, not as much economic as social and thus a clear and visible demonstration of strength and power on the part of the lords over their submitted vassals ${ }^{56}$. The supplies of food granted in order to keep the English lords' households for a specific amount of time could be considered as genuine rent in food and this used to consist of hundreds of loaves of bread, many barrels of ale, cattle, sheep, bacon, and dozens of cheeses ${ }^{57}$. This demanding income on food was also fairly common in Galicia that for the purpose of honouring the patron saint festivities of the monastic states, as well as under various forms of levy such as servicio or colleita, the peasant was obliged to fill the lords' larders with bread, meat, and wine ${ }^{58}$.

There were other seigneurial engagements related to labour services, but of a different nature that the peasants had to carry out: mainly those devised to produce an improvement of the tenure given away in exchange for rent. These sorts of obligations were commonly shared by both English and Galician tenants and, in most cases, were arisen from the lord's wish to increase the production of soil at the expense of the effort of their vassals by transforming the woodland and the waste into arable soil59. In addition, peasants were committed to keeping the landholding in a good state by preventing houses and buildings from being dilapidated or even by building new premises in order to enhance the agrarian output ${ }^{60}$.

Luctuosa and heriot as are known the death duties deployed to be satisfied by both Galician and English landholders, held a great significance for rural family lives. Initially, it was an institution of Indo-European origin conceived as

55. Álvarez Álvarez, Eleutino: 'El yantar y el hospedaje foral en el sur de Galicia (1340-1450)', Boletín Auriense, 13 (1983), pp. 137-144.

56. FERNÁNDEZ CONDE, Francisco Javier: El señorío del cabildo ovetense: estructuras agrarias de Asturias en el tardo medievo, Oviedo, Universidad de Oviedo, 1994, p. 154.

57. DYER, Christopher: Making a living in..., pp. 27-28.

58. Lucas Álvarez, Manuel \& Lucas Domínguez, Pedro: El monasterio de San Clodio do Ribeiro en la Edad Media: estudio y documentos, A Coruña, Do Castro, 1996, p. 181. Lucas Álvarez, Manuel \& LuCAS Domínguez, Pedro: El priorato benedictino de San Vicenzo de Pombeiro y su colección diplomática en la Edad Media, A Coruña, Do Castro, 1996, p. 45.

59. Ló Pez SABATEL, José Antonio: 'Uso y transformación en espacio agrario del monte y del estrato arbóreo en la Ribeira Sacra durante los siglos xIv y xv', Cuadernos de Estudios Gallegos, 122 (2009), pp. 213-233. SCHOFIELD, Philipp.R. Peasant and community in..., p. 25.

6o. DYer, Christopher: Everyday life in..., p. 137. López SABATEL, José Antonio: 'Aproximación al suelo habitable en la Ribeira Sacra durante los siglos xIV y XV', Espacio, Tiempo y Forma. Serie III, 19 (2006), pp. 293-303. 
compensation received by the freeman owner in the event of the death of one of his vassals ${ }^{6}$. However, there seemed to have been quite substantial differences between how this levy was to be required by both Galician and English lords. While in England, it is true that the heriot remained as a tax on chattels throughout this period and required the best or second best animal ${ }^{62}$, conversely, in Galicia just as in Castille, this burden had to be paid in cash $^{63}$. As a matter of fact, the heriot only would be accepted in money in case the peasant had no chattel to offer. Therefore this method to raise income became popular on the part of the lords in order to prevent the frequent concealment of livestock undertaken by the vassals to avoid paying this imposition ${ }^{64}$. Another formal difference between these death duties lay in from whom and how this revenue was collected. In Galicia, for instance, the luctuosa was meant to be paid after the death of each tenant by the next generation entitled to inherit the land as agreed in the agrarian contract; consequently, this could be considered as a kind of inheritance tax. In England, the heriot was usually taken away from the estate of the deceased. However, this tribute did not usually charge the land whenever this passed to an heir who had already paid an entry fine ${ }^{65}$. This absence of succession traits regarding the heriot stands out as the lords, in order to secure its collection beforehand, used to encumber land transactions carried out by elderly tenants ${ }^{66}$. Such a way of proceeding with respect to the heriot can be explained due to the lack of inheritance rights fixed in the villein status within the feudal framework. Nonetheless, despite the fact that the land legally belonged to the lords and was theoretically retrievable at their will, in practice, the manor court used to enforce and respect local custom regarding both inheritance and transactions ${ }^{67}$.

\section{TIED TO THE LAND}

The subordination of peasants to the land was a common feature in the medieval countryside landscape across Europe. In England, the tenant was subjected to the discipline of the manor that prevented him from moving without the permission of his lord ${ }^{68}$.This restriction of mobility was also common in Galicia and its origin is

61. Pena Graña, Andrés: 'Galicia, cuna de los celtas de la Europa Atlántica', Anuario brigantino, 30 (2007), pp. 57-88.

62. GIES, Frances \& GIES, Joseph: Life in a Medieval Village, New York, Harper \& Row, 1990, p. 76.

63. Clemente Ramos, Julián: 'Mañería y nuncio en el Becerro de las Behetrías', Norba. Revista de historia, 7 (1986), pp. 71-80.

64. SCARDellato, Gabriele Prieto: Medieval Records of Obersley Manor (Rentals and Court Rolls, 1300-1500), Doctoral Thesis, Vancouver, University of British Columbia, 1983, p. 261.

65. BAILEY, Mark: Medieval Suffolk..., p. 56.

66. Postan, Michael Moïssey: Essays on medieval..., p. 153.

67. Gold berG, Peter Jeremy: Medieval England. A Social History, 1250-1550, London, Bloomsbury Academic, 2011 , p. 91.

68. Given-WiLson, Chris: An illustrated History of Late Medieval England, Manchester, Manchester University Press, 1996, p. 42. 
rooted in the concept of dependent peasants as a part of the estate where they live just like livestock. Thus, they share the same fate in the case that the land would be alienated. An example of this was several donations received by the monastery of Samos during the tenth and eleventh centuries, by which serfs constituted one indivisible lot alongside lands and the rest of the properties ${ }^{69}$. A similar case happened in Wiltshire in the early tenth century, when the bishop of Winchester leased an estate at Ebbesbourne and with the land; the lessee received six serfs with their offspring ${ }^{70}$. This agricultural workforce, both in England and Galicia, shared a general category of personal and economic dependence by remaining tied to the land and not free to go where they please ${ }^{71}$.The reason for that lay in the interest showed by lords in keeping the land populated, even by forcing peasants to take up tenements under seigneurial jurisdiction. Consequently, both English villeins and Galician tenants were not allowed to alienate the tenure without the lord's permission and, once given the nod, the new landholder would have to enjoy the same legal status as his predecessor ${ }^{72}$. Whenever the landholder left the coto without the lord's permission, the agrarian contract by which he was allowed to till the land would be annulled ${ }^{73}$. Therefore, freedom of movement was only possible as long as the same would not lead to prejudice for the lord ${ }^{74}$. Owing to the condition of the tenant as a true asset within the manor, the lord would require the payment of the chevage as a compensation for migrating villeins, so that if the tenant wished to leave the manor, he would have to satisfy a yearly fee, at Elton, for instance, usually by providing two chickens or capons ${ }^{75}$. Although there was no chevage in Galicia, if an heir happened to inherit tenure within the coto and decided to live outside its boundaries, he would be forced to pay derechura as acknowledgement of lordship ${ }^{76}$.

69. Lucas Álvarez, Manuel: El Tumbo de San Julián de Samos (siglos vil-XII): Estudio introductorio. Edición diplomática. Apéndices e índices, Santiago, Caixa Galicia, 1986, pp. 73, 211 and 277-279.

70. WOOD, Michael, Domesday. A Search for the Roots of England, London, BBC Books, 1990, p. 150.

71. IsLA Frez, Amancio: La sociedad gallega en la Alta Edad Media, Madrid, CSIC, 1992, pp. 228-234. Wood, Michael: Domesday..., p. 154.

72. Ríos Rodríguez, María Luz: As orixes do foro..., p. 230.

73. '...et demais se vos o dito Martino ou a dita vossa muller o perssona vos fordes morar fora do dito couto de Doade san nosa liçençia que este foro todo seia vago en nosas maos et que nos o dito don abbade et convento posamos del proveer a quen por ben tevernos sen pena ningua...', Archive of San Vicente del Pino de Monforte, Folder 1, n. ${ }^{\circ}$ and 26 ; Folder 4 , n. ${ }^{\circ} 13$.

74. MARTín, José Luis: '¿Campesinos de remensa en Castilla y León? (siglos XII y XIII)', la España Medieval, 3 (1982), pp. 37-48.

75. RATCLIfF, Sidney Charles: Elton Manorial Records, 1279-135/, Cambridge, Roxburghe Club, 1946, pp. 147-151.

76. '...e se os ditos herdeiros labraren outras herdades, que non sejan deste dito lugar, que paguen os foros miudos ao dito moesteiro, e non sejan quitos, salvo o que morar o dito lugar...', LUCAS ÁlvarEZ, Manuel \& LUCAS DomínguEZ, Pedro: El priorato benedictino de..., pp. 218-219. 


\section{PEASANTRY AS A DIVERSIFIED CLASS}

It would be wrong to think of the peasantry as an only homogeneous and impoverished social class. One of the first attempts to conduct a social study of medieval England pointed out the difficulty of establishing generalizations regarding the state of those who tilled the soil; namely, the bulk of the population ${ }^{77}$. The legal status by itself would not be determinant enough to constitute substantial differences in the rural social structure. When the royal serfs on the manor of Witham in Somerset were given the choice between being resettled to another royal manor with tenures of the same size or of being granted their freedom, some chose the land and others freedom ${ }^{78}$. Peasantry's wealth and income would be articulated by a wide range of variables devised to set up the peasant's daily economic well-being. Of these variables, one of most significant lay not only in the size of the landholding at the tenant's disposal79 but also in the commercial economy based on the land market, which allowed the better-off peasants to acquire land not in order to guarantee their subsistence, but either to expand their profitable agricultural production or, in most cases, as a strategy to earn a considerable amount of cash by subletting properties to other peasants. A few entrepreneurs accumulated great wealth at the expense of their less able or fortunate neighbours $^{80}$. Consequently, there is a pattern of a small number of wealthy peasants who managed to increase the size of their holdings. This was the case of Martin Suvel, in the Norfolk village of Sedgeford. He inherited 3 acres of land and by 1282 had built up a holding of over 35 acres $^{8 \mathrm{I}}$. Likewise, John de Heworth, a Dunham priory tenant, accumulated over 280 acres between 1315 and 1345 and amassed such a fortune that he was appointed to lead a force of almost 200 mounted archers on the Scottish expedition of $1335^{82}$. Furthermore, the sternness of inheritance customs meant that many villeins had to buy, sell, and lease land if they were to make a decent living. Therefore, getting involved in the land market would be a necessity rather than an option ${ }^{83}$. In Galicia, apart from the size of the holdings and the sale of the agricultural surpluses in the market, it was the possession of oxen that had a huge impact upon the socioeconomic differentiation amongst the peasantry. Monasteries used to require tenants to supply at least two oxen in

77. BAteson, Mary: Medieval England, 1066-1350, London, T. Fisher Unwin, 1903, pp. 96-97.

78. Doule, Decima \& Farmer, David Hugh: Magna Vita Sancti Hugonis: Volume I: The Life of St. Hugh of Lincoln, Oxford, Oxford University Press, 1985, p. 62.

79. DYER, Christopher: Standards of Living in the Later Middle Ages: social change in England c. 1200-1520, Cambridge, Cambridge University Press, 1998, pp. 109-150.

80. Coss, Peter: lordship, Knighthood and Locality: A Study in English Society, c.1180-1280, Cambridge, Cambridge University Press, 2004, pp. 131-134.

81. Harvey, Philip D.A.: The Peasant Land..., pp. 69-70, 95.

82. LongSTAFFE, William Hylton Dyer \& BOOTH, John: Halmota prioratus dunelmensis, Durham, Andrews \& co., 1889, pp. 14-16.

83. BAIGENT, Francis Joseph: A collection of records and documents relating to the hundred and manor of Crondal in the county of Southampton, vol. 1, London, Simpkin \& CO, 1891, pp. 145-146, 152-153. 
order to ensure the full exploitation of the tenure ${ }^{84}$ and this figure seems to draw the difference between affluent and impoverished peasants ${ }^{85}$. Given that not all farmers could meet such requirements, the lack of homogeneity in the Galician countryside seems clear $^{86}$.

Another way to boost the socioeconomic differentiation in both English and Galician countryside was tightly linked to a seigniorial policy aimed at strengthening strategic alliances with leading members of the rural community who began to appear in documents from early medieval western Europe under the name of boni homines. This group of influence soon would take on special assignments either in the lord's court or as rent collectors ${ }^{87}$.Over the late thirteenth century in Galicia, selected members of the peasantry, in return for better conditions in their agrarian contracts, acted as lords' agents in order to ensure the full performance of the seigneurial holdings ${ }^{88}$.It is also important to note the role played by Galician boni homines, right from the early Middle Ages, as mediators in court proceedings ${ }^{89}$. In England, the same happened there as in north-west Spain where agents called reeves were recruited by the lords from the ranks of their customary tenants, thus following a practice rooted in the Anglo-Saxon period ${ }^{\circ}$. Those who held the largest tenures used to be the best candidates to help the lords stretch their control over the manor. Furthermore, these upper class peasants were compelled to act as juries as well as overseers to the labour services carried out by the rest of the tenants ${ }^{91}$. The reeves used to shoulder a wide variety of responsibilities on behalf of their lord. In the first place, they acted as judges in the manorial court and, consequently, they had to show a detailed knowledge of the customs of the manor and the law of the land ${ }^{92}$. On the other hand, these local agents not only used to collect rent and gifts from the lords' domains, but also to represent their wills when giving seisin of the land ${ }^{93}$. Finally, the reeves were also in charge of supervising the lord's harvest and his woodland, extending his rights across neighbouring areas and even managing the manorial demesne ${ }^{94}$.

\footnotetext{
84. MARIÑO VEIRAS, Dolores: Señorío de Santa..., p. 313.

85. Clemente Ramos, Julián: La economía campesina en la corona de Castilla (1000-1300), Barcelona, Crítica, 2004, p. 81.

86. Ríos Rodríguez, María Luz: 'Transformación agraria. Los terrenos de monte y la economía campesina', in TORRES, María del Pilar et alii (coord.): Espacios rurais e sociedades campesiñas, Santiago de Compostela, Universidad de Santiago de Compostela, 1998, pp. 145-172.

87. BONNASSIE, Pierre: Del esclavismo al feudalismo en Europa occidental, Barcelona, Crítica, 1993, p. 149.

88. Ríos Rodríguez, María Luz: 'Estrategias señoriales en Galicia: las instituciones eclesiásticas y sus relaciones contractuales con la nobleza laica (1150-1350)', in PASTOR, Reyna et alii: Poder y sociedad en la Galicia medieval, Santiago de Compostela, Tórculo Edicións, 1992, pp. 175-189.

89. Davies, Wendy: 'Summary Justice and Seigneurial Justice in Northern Iberia on the Eve of the Milennium', The Haskins Society Journal, 22 (2010), pp. 43-58.

90. Andrews, Charles McLean: The Old English Manor. A Study in English Economic History, Baltimore, The John Hopkins Press, 1899, p. 135.

91. BENNET, Henry Stanley: Life on the English..., p. 64

92. ANDREWS, Charles McLean: The Old English..., p. 139.

93. Greenway, Diana: Charters of the honour of Mowbray, 1107-1191, Oxford, Oxford University Press, 1972, pp. 152-155.

94. Harvey, Philipp D.A.: Manorial Records, London, British Records Association, 1999, p. 30.
} 


\section{DAILY RESISTANCES}

According to the traditional typology developed by Porshnev, the open uprising was the primary form of peasant resistance, while partial resistance was considered as a secondary mode. This latter modality, conceptually defined as latent or, in words of James C. Scott, as 'everyday forms of resistance' 95 , would include both personal and collective rejections and infringements to the seigneurial obligations and prohibitions. Litigations conducted in defense of the peasants' rights, and, finally, the flight as a definitive sign of disobedience to the feudal regime were also common forms of resistance ${ }^{96}$. Nor must we forget the daily opposition of the tenants against their lord's will in the form of an attitude of non-cooperation reflected in the deviation of a part of the rent, deliberate delays, and even small sabotages ${ }^{97}$.Lastly, it would be appropriate to remember how important the struggle undertaken by the tenants against the lords for the agricultural and livestock spaces became in the early Middle Ages in order to minimize their dependence ties ${ }^{98}$.

In Galicia, one of the most usual ways for the peasantry to express their discontent with the lordship was to commit a total or partial breach of the clauses of the foro. Thus, taking a plot without lord's permission ${ }^{99}$, continuing to till the land once the contract was terminated ${ }^{\mathrm{IoO}}$, refusing to pay the rent ${ }^{\mathrm{IoI}}$ and, finally, failing to fulfil the conditions stipulated in the foro were all clear signs of defiance against the feudal framework. In England, it was also common to find illegal encroachments of land carried out by tenants against the will of those in authority. This trespassing had to be settled in the manorial court by fining those who could not prove their rights over the seized plots $^{102}$. Throughout the thirteenth and fourteenth centuries, there were plenty of acts of general resistance to the lord's exactions; one of the most significant took place in Thornbury (Gloucestershire) where 759 examples of resistance via labour services were recorded in the manor court during the second quarter of the fourteenth century ${ }^{103}$. The fine was most commonly used by the lords to settle such misbehaviours. At Abbot's Langley in I282, the entire village community refused to reap the harvest and a fine of 18

95. ScOtT, James C.: Weapons of the Weak: Everyday Forms of Peasant Resistance, New Haven, Yale University Press, 1985.

96. RösEner, Werner: Los campesinos en la Edad Media, Barcelona, Crítica, 1990, p. 252.

97. Freeman, Paul: 'La resistencia campesina y la historiografía de la Europa medieval', Edad Media: Revista de Historia, 3, (2000), pp. 17-38.

98. FeRnÁNDEZ CONDE, Francisco Javier: La España de los siglos xIII al xV. Transformaciones del feudalismo tardío, San Sebastián, Nerea, 2004, p. 117.

99. Lucas Álvarez, Manuel \& Lucas Domínguez, Pedro: El monasterio de San Clodio..., pp. 446-447.

100. Idem, El priorato benedictino de..., p. 113.

101. Idem, El monasterio de San Clodio..., p. 338.

102. НоввS, Daphne Angela: Manor Village and..., pp. 90-91.

103. Franklin, Peter: 'Politics in Manorial Court Rolls: The Tactics, Social Composition, and Aims of a pre-1381 Peasant Movement', in RAZI, Zvi \& SMITH, Richard (eds.): Medieval Society and the Manor Court, Oxford, Oxford University Press, 1996, pp. 166, 176-177. 
shillings was levied. On the Ramsey manor of Broughton in I29I, the tenants refused to carry out their autumn boon works, arguing that they had not received the bread to which they were entitled, and eventually the manor court imposed a fine of 40 shillings ${ }^{104}$. By that time, in Galicia, the inhabitants of Pedrafita and San Vicente de Muros refused to pay ominous burdens, such as the mañeria, conducho, and facendera to the monastery of Oseira and the bishopric of Lugo, respectively ${ }^{105}$. It was also common to find English unfree tenants trying to purchase free land and avoid paying merchet, tallage, chevage, and heriot, as well as, fines for the education of their offsprings ${ }^{\mathrm{Io6}}$. Litigations were another method to challenge the lord's authority shared by both English and Galician peasantry. In this case, Galician peasants enjoyed a similar legal status to that of freemen due to their capacity, at least theoretically, to bring their claims to the royal courts. In this way, trials soon became the best platform to solve day-to-day anti-seigneurial conflicts ${ }^{107}$. In most cases, the matters in dispute used to be related both to the right to exploit land and propriety rights. The parties often used to reach an agreement by which the tenant would have to waive his rights in exchange for a considerable amount of cash as compensation ${ }^{\mathrm{I0} 8}$. On the other hand, the interest of the village communities not only would settle for undermining the territorial lords' heritage to their advantage, but they also intended to take away jurisdictional competences from them. This was the case of the neighbours of Castrodor, who claimed that they were men of the crown and in no case vassals of the bishop of Mondoñedo, for they had populated their village according to the charter of privileges of Benavente ${ }^{\mathrm{I09}}$. In England, most judicial pleas were aimed at challenging the legal status of both the land and its inhabitants. Thus the tenants of the Abbey of Bury St. Edmunds at Mildenhall claimed the ancient demesne status of the land they tilled and, therefore, their right to be considered as free men because of their proven association with the crown ${ }^{\text {II }}$. In some cases, like in Garthorpe (Leicestershire), tenants simply claimed that they were free ${ }^{\mathrm{II}}$. Likewise, the peasants at Wawne claimed that they were not villeins of the nearby Abbey of Meaux. Despite the fact that the abbot imprisoned the leaders, in the end, they

\footnotetext{
104. Raftis, James Ambrose: Tenure and Mobility: Studies in the Social History of the Mediaeval English Village, Toronto, Pontifical Institute of Mediaeval Studies, 1964, p. 108.

105. Romaní Martínez, Miguel: Colección Diplomática do mosteiro cisterciense de Sta. María de Oseira (Ourense) 1310-1399, Santiago de Compostela, vol. 1, Tórculo Edicións, 1993, pp. 464-465. SánCHEZ BeLDA, Luis: Documentos reales de la Edad Media referentes a Galicia. Catálogo de los conservados en la sección de clero del Archivo Histórico Nacional, Madrid, Servicio de publicaciones del ministerio de educación nacional, 1953, pp. 331-332.

106. SChofield, Philipp. R.: Peasant and community in..., p. 162.

107. Alfonso Antón, Isabel: 'Campesinado y derecho: la vía legal de su lucha (Castilla y León, siglos X-XIII)', Noticiario de Historia Agraria, 13, (1997), pp. 15-32.

108. Romaní Martínez, Miguel: Colección diplomática..., vol. 2, pp. 1118-1119, 1174-1175, 1247.

109. AHN, Sección clero, Carpeta 1188, n. ${ }^{\circ} 11$. Ed. SÁNCHEZ BeLDA, Luis: Documentos reales..., pp. 387 and 407-408.

110. SCHOfield, Philipp. R.: Peasant and community in..., p. 163.

111. Alekseevich Kosminskil, Evgenii: Studies in the Agrarian History of England in the Thirteenth Century, Oxford, Blackwell, 1956, p. 344.
} 
were able to take their case forward using the mechanisms of the law. Lengthy judicial proceedings followed, in which the abbey was eventually successful ${ }^{\mathrm{II}}$.

The unlicensed departure of the villains from their lords' manors in search of better conditions of living somewhere else was, without any doubt, the extreme sign of non-compliance. These flights are recorded in both English and Galician medieval documentation. In II82, inhabitants of cotos under the jurisdiction of the bishopric of Lugo decided to flee to the town and Ferdinand II, at the request of the bishop, urged the gentry of Lugo not to give shelter to the fugitives. A similar situation happened one century later when neighbours of Villamayor took up residence in Monterrey refusing to pledge allegiance to the monastery of Santa María de Melón. Once again, the royal intervention was necessary, in this case, by forcing the rebellious villagers to return to the monastery's domains and pay several jurisdictional levies ${ }^{\mathrm{II}}$. In England, the mediation of the king in these matters was also common. The so-called Laws of William I ruled, 'Serfs shall not leave their lands nor seek devices to defraud their lord of the service they owe' Following this pattern, Norman and Angevin kings were always willing to issue writs for their officials to secure the return of runaway peasants to their lords. William Rufus commanded his officials to persecute the tenants who left the lands of the abbey of Ramsey without permission ${ }^{\mathrm{II}}$. Likewise, Henry I instructed all his sheriffs and officials to find and restore the fugitives who had fled from the lands of the abbey of Abingdon. Furthermore, the writ specifies a fine of ten pounds for anyone retaining them unjustly ${ }^{\mathrm{II}}$. Moreover, In Spain, Alphonse xI directed a writ to the royal authorities warning them about the frequency and facility with which the runaways were able to get help and shelter from their neighbours ${ }^{\mathrm{II} 7}$. Here it is seen that their resistance was not strictly confined to the flight but also to the ties of solidarity showed by those who felt oppressed within the feudal framework.

\section{CONCLUSION}

As for Galician territory and thanks to the triumph of the indirect management of the soil, it seems to be that the dependency bonds of peasantry were, somehow, much looser than those suffered by English villeins. Direct management led to

\footnotetext{
112. Bond, Edward A.: Chronica monasterii de Melsa: a fundatione usque ad annum 1396, vol. 3, London, Longmans, Green, Reader and Dyer, 1866-69, pp. 127-142.

113. SÁnChez BeLdA, Luis: Documentos reales..., p. 352.

114. Robertson, Agnes: The Laws of the Kings of England From Edmund to Henry I, Cambridge, Cambridge University Press, 1925, p. 268.

115. MACRAY, William Dunn: Chronicon Abbatiae Ramesiensis a saec. $x$ usque ad an. circiter 1200, Cambridge, Cambridge University Press, 2012, p. 212.

116. Stevenson, Joseph: Chronicon Monasterii de Abingdon: Volume 2, From the Norman Conquest Until the Accession of Richard the First, Cambridge, Cambridge University Press, 2012, pp. 81-82.

117. Romaní Martínez, Miguel: Colección diplomática..., vol. 3, pp. 191-192.
} 
the survival of older models of subjugation since seigneurial income used to rely heavily on labour services of customary tenants. In fact, when it comes to sheer economic terms, the Galician peasantry shared the same status as English freemen, for both of them had to satisfy a pre-set rent in exchange for working the lord's land. Another factor that strengthened the differentiation in both territories was the nature of seigniorial power in itself. Whilst in England, at best the custom of the manor, and at worst the whimsical lord's will ruled the entire countryside, in Galicia the lordship stretched out by means of two-sided agrarian contracts which were biding before the law. In this way at least, and in theory, Galician peasants were able to enter into litigation in the royal courts, whereas customary tenants had to rely on the manor courts which were heavily weighted toward the interest of the lord of the manor. While it is true that it was under the tenurial lordship where one can find major differences with respect to everyday peasants' lives for both territories, it was nevertheless clear that it was jurisdictional rights which forced English and Galician peasantry to share a similar subdued condition by bearing onerous burdens. Consequently, it can be argued that the main distinction in status consisted of the diverse models of farming since the subordination to the jurisdictional power exercised by lords was a common place for both Galician and English tenants. Moreover, another close similarity refers to the hierarchical organization of the peasant society, mostly as a result of the special relationship of part of its members with the overlords, while at the same time, some of the less fortunate tried to mount an everyday resistance against such an overwhelming seigniorial system. Silent and latent actions under which peasantry intended to gain enough resources at cost of lords' privileges in order to guarantee a bare daily subsistence and, occasionally, open and violent uprisings from which part of the peasants triggered a reaction headed to contest seigneurial prerogatives. 